\title{
Activities of the Canadian Association of Gastroenterology Endoscopy Committee
}

Jonathan Love MD FRCPC

Chair, CAG Endoscopy Committee

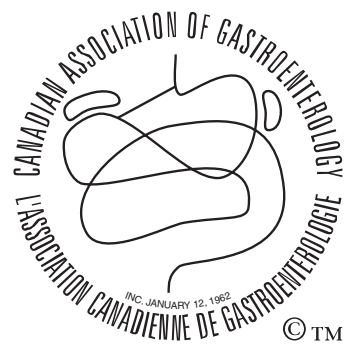

En français voir page 344

$\mathrm{T}$ he Endoscopy Committee of the Canadian Association of Gastroenterology (CAG) has been active on a number of issues that have a direct impact on the clinical practice of our members, with progress on some of them.

\section{CANADIAN GUIDELINES ON FLEXIBLE ENDOSCOPE REPROCESSING}

CAG, in partnership with with Health Canada, has formed a task force on flexible endoscope reprocessing that will provide an up-to-date, Canadian reference for anyone who uses or cares for flexible endoscopes. A number of incidents that have been reported in the media over the past few years have shown how necessary this is.

The proceedings will be published in the Canadian Communicable Diseases Report, with copublication in The Canadian Journal of Gastroenterology. The expected date of completion is 18 months from now. Anyone who would like to make a submission to the committee is encouraged to contact one of the cochairs: Dr Anne Matlow, Division of Infectious Diseases, Hospital for Sick Children, Toronto, Ontario (e-mail anne.matlow@sickkids.ca) or myself, Dr Jonathan Love, Department of Gastroenterology, QEII Health Sciences Centre, Halifax, Nova Scotia (e-mail jlove@dal.ca).

Preliminary drafts of the publication will be available for public review on the Health Canada Web site when ready.

\section{CANADIAN CONSENSUS ON THE MANAGEMENT OF UPPER GASTROINTESTINAL BLEEDING}

A Consensus Conference, chaired by CAG member Dr Alan Barkun, was held in Banff, Alberta in June 2002, under the auspices of the CAG Endoscopy and Practice Affairs Committees. Dr Barkun should be congratulated for his hard work and successful staging of this important con-

ference. Draft guidelines are presently in circulation to participants in anticipation of publication late this year.

\section{ORAL SODIUM PHOSPHATE FOR COLONOSCOPY PREPARATION}

Health Canada issued an advisory on April 4, 2002 reminding practitioners who use sodium phosphates oral solutions of important safety concerns. This issue continues to be raised by practising gastroenterologists. The Endoscopy Committee is in contact with Health Canada to get clarification and to consider carefully the relative risks and benefits of bowel cleansing in a clinical context. I have written a letter to the Editor-in-Chief of The Canadian Journal of Gastroenterology on this issue.

\section{NURSE SCHOLARSHIP PRIZE}

The Endoscopy Committee adjudicates the CAG Nurse Scholarship Prize for the Canadian Society of Gastroenterology Nurses \& Associates. The winners for 2002 were: Endoscopy Nurse Prize, Denise Thomson, Brandon, Manitoba and Research Nurse, Cindy James, Ancaster, Ontario. These prizes are $\$ 500$ each, and are awarded to help defray the costs of attending the Canadian Digestive Diseases Week conference. Details for applications are available from the CAG head office at CAG, 2902 South Sheridan Way, Oakville, Ontario L6J 7L6, telephone 888-780-0007 (toll free) or 905-829-2504, fax 905-8290242, e-mail cagoffice@ cag-acg.org.

Finally, as I finish my term, I would like to thank the Association for the opportunity to serve as chair of the Endoscopy Committee. Please welcome the new chair, Dr Robert Enns (Vancouver, British Columbia) and his enthusiastic members, Dr Jonathan Springer (Toronto, Ontario), Dr Joseph Romgnuolo (Calgary, Alberta) and Dr Terry Ponich (London, Ontario). I know one of the exciting projects they are already working on is a national endoscopy database.
Abbott Laboratories Ltd.
AstraZeneca Canada Inc.
Axcan Pharma Inc.
Janssen-Ortho Inc. 


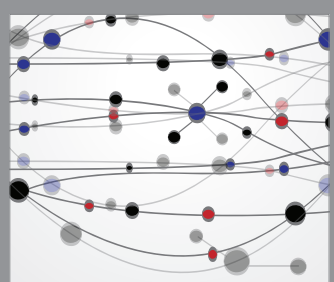

The Scientific World Journal
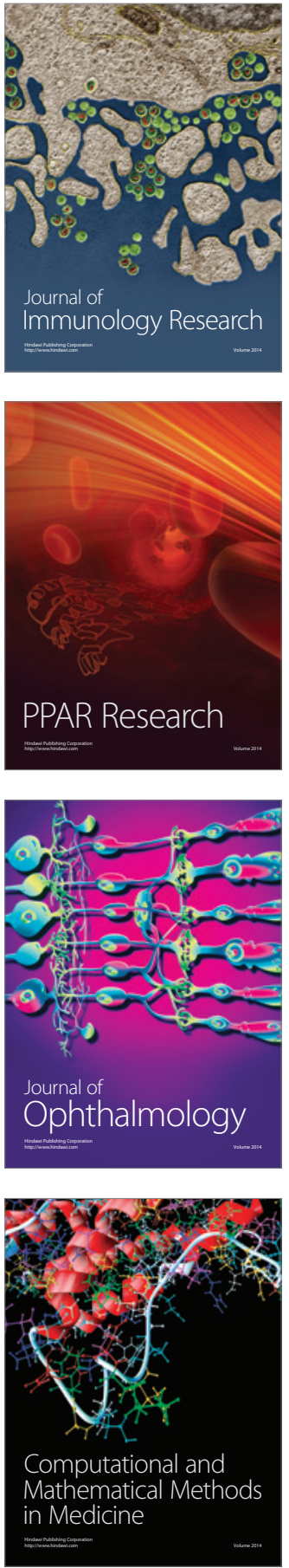

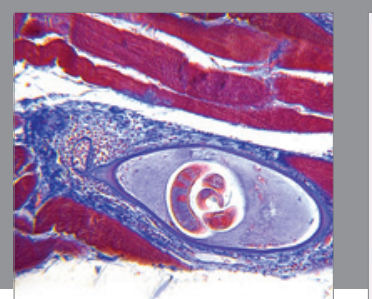

Gastroenterology Research and Practice

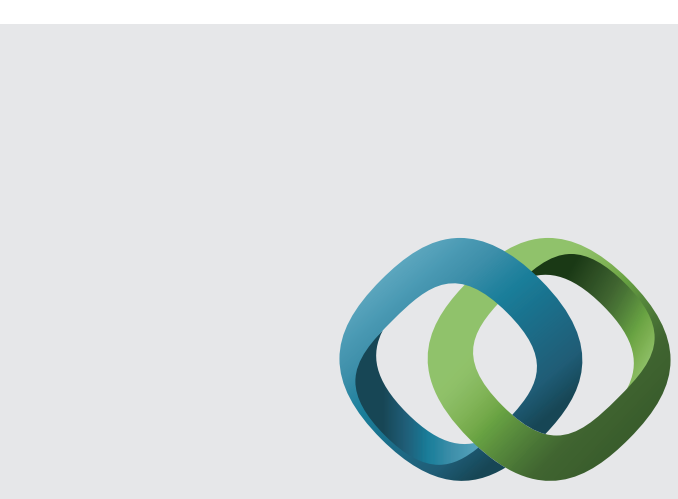

\section{Hindawi}

Submit your manuscripts at

http://www.hindawi.com
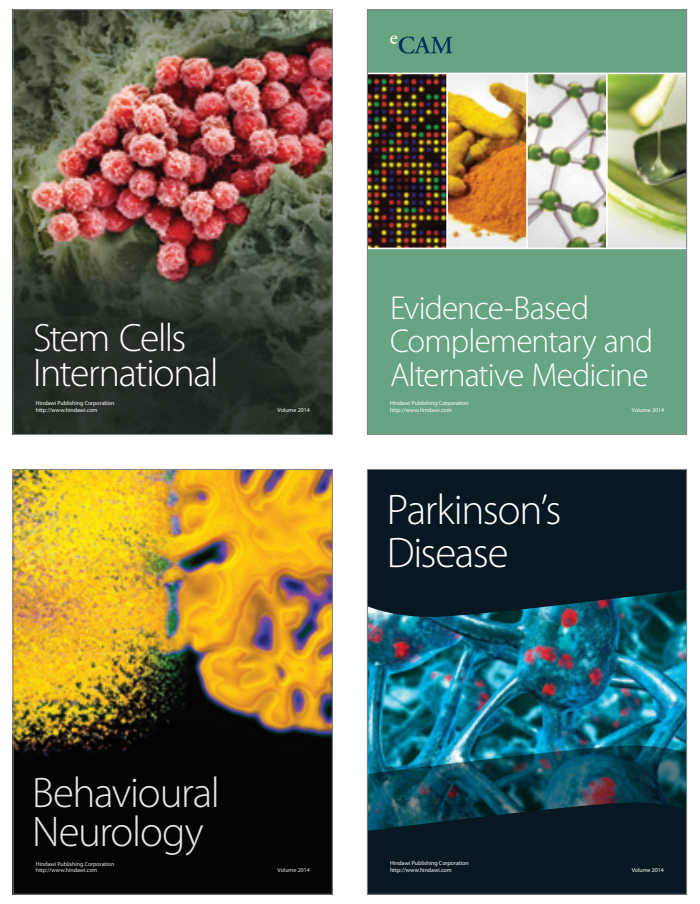
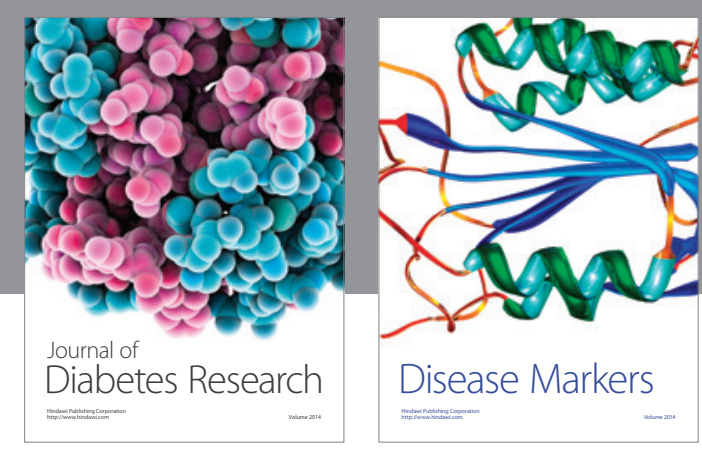

Disease Markers
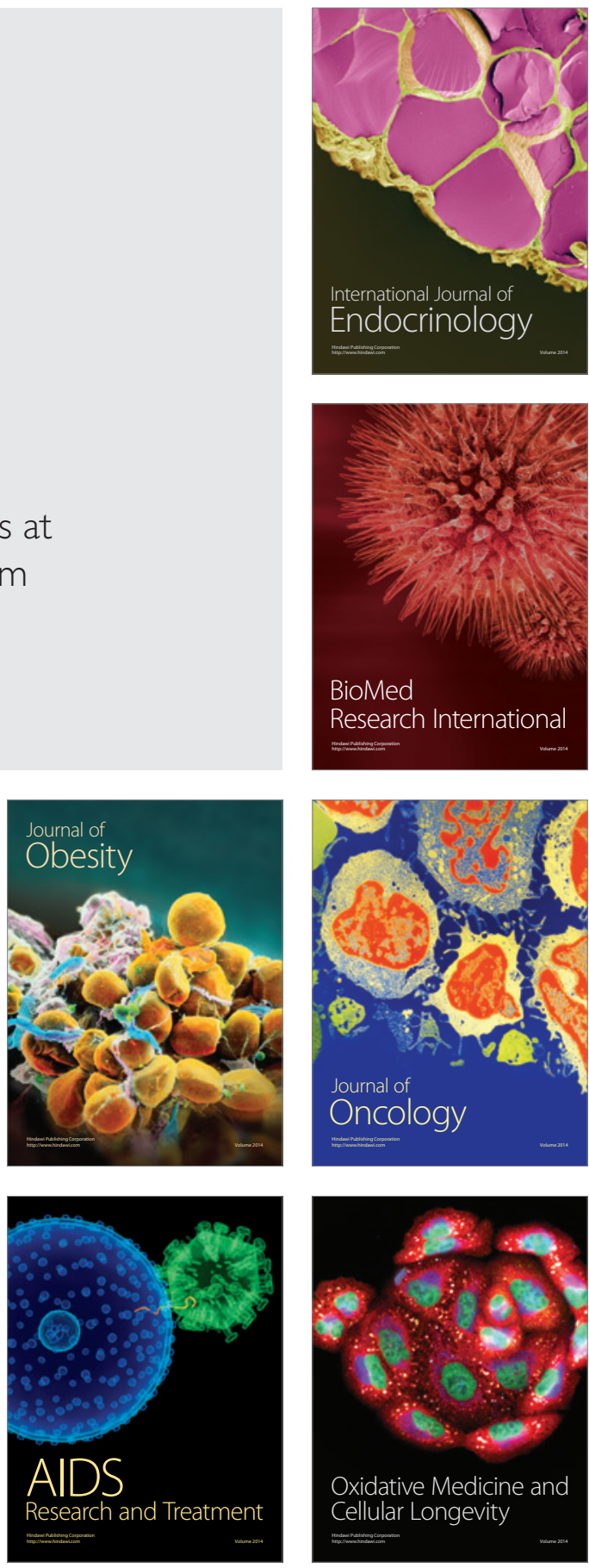